\title{
RUMUSAN STRATEGI PEMASARAN DALAM PENJUALAN PRODUK DENGAN METODE SWOT DAN QSPM (Quantitative Startegic Planning Matrix) (Studi Kasus CV. Bimanda Elektronik Pekanbaru)
}

\author{
Ahmad Nurul Sabry \\ Program Studi Teknik Industri, Fakultas Teknik, Universitas Muhammadiyah Riau \\ Jalan Tuanku Tambusai Ujung, Kecamatan Tampan, Kelurahan Delima, Kota Pekanbaru, Riau 28291
}

Email : sabrypratama26@gmail.com

\begin{abstract}
$C V$. Bimanda Elektronik is a company engaged in the sale of electronics. Based on a preliminary survey, which is a decline in sales every month in the 2019 period. The marketing strategy used by CV. Bimanda Elektronik at the moment is using word of mouth promotion. This research was conducted to identify and analyze the company's internal and external environmental factors that affect the marketing strategy of electronic product marketing and to design marketing strategies using the SWOT and QSPM methods. Based on the objectives, the company's main strength is the competitive market price with a score of 0.249 and the company's main weakness is not using a website or database system with a score of 0.092. While the main opportunity that the company has is the high consumer loyalty to the company's products with a score of 0.358 and the company's main threat is the number of substituted products with a score of 0.311. By using the SWOT and QSPM methods, there is a marketing strategy that can be used by companies, namely carrying out promotional and advertising activities to attract potential customers and expand the marketing area with a TAS score of 6.568.
\end{abstract} Keyword: External, Internal, SWOT Matrix, QSPM.

ABSTRAK

CV. Bimanda Elektronik adalah perusahaan yang bergerak dibidang penjualan elektronik. Berdasarkan survey pendahuluan yang yaitu terjadinya penurunan penjualan setiap bulannya pada periode 2019. Strategi pemasaran yang digunakan CV. Bimanda Elektronik pada saat ini adalah dengan mengguakan promosi dari mulutkemulut. Penelitian ini dilakukan untuk mengidentifikasi dan menganalisis faktor-faktor lingkungan internal dan eksternal perusahaan yang mempengaruhi strategi pemasaran pada pemasaran produk elektronik dan merancang strategi pemasaran dengan menggunakan metode SWOT dan QSPM. Berdasarkan tujuan, maka diperoleh kekuatan utama perusahaan adalah harga dipasar bersaing dengan skor 0,249 dan kelemahan utama perusahaan adalah tidak menggunakan website atau sistem database dengan skor 0,092. Sedangkan peluang utama yang dimiliki perusahaan adalah tingginya loyalitas konsumen terhadap produk perusahaan dengan skor 0,358 dan ancaman utama perusahaan adalah banyaknya produk substitusi dengan skor 0,311. Dengan menggunaka metode SWOT dan QSPM didapatkan strategi pemasaran yang dapat digunakan oleh perusahaan yaitu melakukan kegiatan promosi dan iklan untuk menarik pelanggan potensial dan memperluas daerah pemasaran dengan skor TAS sebesar 6,568

Kata Kunci : Eksternal, Internal, Matriks SWOT, QSPM. 


\section{PENDAHULUAN}

Pertumbuhan usaha dalam menghadapi persaingan bisnis di wilayah Indonesia merupakan suatu hal yang menarik yang perlu diikuti dan perlu disimak, terlebih lagi dalam hal adanya perubahan globaliasi terhadap bidang ekonomi saat ini yang semakin membuka peluang terhadap pengusaha asing yang turut berkompetensi dalam mendapatkan konsumen lokal. Dampak dari perubahan globalisasi yang terjadi menyebabkan perusahaan jasa dari berbagai macam usaha sperti perusahan elektronik, telekomunikasi dan transportasi berkembang dengan sangat pesat.

Perusahaan yang baik pasti akan memikirkan masa depan dari keberlangsungan perusahaannya yang akan dihadapi perusahaan terhadap pesaing atau saingan yang menjajarkan produk yang sama. Agar perusahan mampu bersaing maka sebuah perusahaan sebaiknya harus mampu mengelola perusahaannya secara baik agar konsumen atau pelanggan tetap memilih dan memberi kepercayaannya kepada perusahaan dan tidak memihak kepada perusahaan yang menawarkan produk yang sama. Perusahaan harus dituntut lebih mengerti keinginan dan kebutuhan konsumen dan pemasaran yang baik pula

CV. Bimanda Elektronik merupakan salah satu CV yang menyediakan berbagai jenis elektronik baik itu mesin cuci, setrika, kipas angin, televisi, kulkas dan produk elektronik lainnya. Perusahaan ini terletak di Jalan Raya Pekanbaru-Bangkinang No.16, Kec. Tambang, Kabupaten Kampar, Riau 28486. CV. Bimanda Elektronik memiliki cabang toko sebanyak 12 unit toko yang tersebar di Kota Pekanbaru. Saat ini perusahaan mengalami penurunan tingkat penjualan. Berikut data penjualan $\mathrm{CV}$. Bimanda Elektronik selama periode 2019.
Berikut data penjualan elektronik $\mathrm{CV}$. Bimanda Elektronik yang mengalami penurunan yang didapat dari toko yang sejenis yang mengalami penurunan penjualan dalam periode tahun 2019 yakni toko pertama berada di Jl. Raya PekanbaruBangkinang No.16 dan toko kedua berada di Jl. HR. Soebrantas Panam.

\section{METODE}

Metode ini melakukan pendekatan melalui analisis dengan metode-metode yang digunakan digunakan ialah Analisis SWOT dan QSPM . Adapun populasi pada penelitian di CV. Bimanda Elektronik ini tidak diketahui atau tak tentu, maka ukuran sampel yang digunakan pada penelitian ini mengikuti pedoman penentuan besarnya ukuran sampel untuk populasi besar atau tak terbatas Metodologi juga digunakan untuk memberi arahan dan mempermudah proses analisis dalam mencar dan menentukan solusi dalam memecahkan masalah, menetukan kualitas dari suatu penelitian dan merancang manajemen penelitian secara baik. Bab ini berisikan mengenai kerangka penyelesaian masalah yang digunakan untuk mendapatkan solusi dari permasalahan yang ada, yang terdiri dari flowchart penyelesaian masalah dan masing-masing langkah dalam melaksanakan penelitian seperti penelitian pendahuluan, perumusan masalah, studi literatur, pengumpulan data sehingga dapat ditarik suatu kesimpulan dan saran. Dalam bab ini akan dijabarkan tentang lokasi penelitian, jenis dan sumber data, populasi dan sampel, teknik pengumpulan data serta analisis data. 


\section{Analisis Lingkungan Internal Perusahaan}

Analisis lingkungan internal ini diperlukan untuk mengetahui kekuatan dan kelemahan bersaing CV. Bimanda Elektronik dengan cara melakukan identifikasi terhadap berbagai faktor-faktor yang ada dalam CV. Bimanda Elektronik. Diantaranya : keuangan, pemasaran, manajemen, penjualan atau produksi, serta penelitian dan pengembangan bahkan informasi manajemen.

\section{Analisis Lingkungan Eksternal}

\section{Perusahaan}

Analisis lingkungan eksternal ini diperlukan untuk mengembangkan sebuah daftar terbatas dari peluang yang dapat menguntungkan sebuah perusahaan dan ancaman yang harus dihindarinya. Lingkungan eksternal perusahaan terbagi menjadi dua yaitu : lingkungan makro dan lingkungan mikro.

\section{Penentuan Populasi dan Sampel}

Populasi adalah totalitas dari semua objek atau individu yang memiliki karakteristik tertentu, jelas dan lengkap yang akan diteliti. Objek atau nilai yang akan diteliti dalam populasi disebut unit analisis atau elemen populasi. Unit analisis dapat berupa orang, perusahaan, media, dan 
sebagainya (Hasan 2012, dikutip oleh

Azirwan, 2014).

Sampel adalah bagian dari populasi yang diambil melalui cara - cara tertentu yang juga memiliki karakteristik tertentu, jelas dan lengkap yang dianggap bisamewakili populasi. Objek atau nilai yang diteliti dalam sampel disebut unit sampel. Unit sampel sama dengan unit analisis, tetapi mungkin juga tidak (Hasan, 2012 dikutip oleh Azirwan, 2014).

Adapun populasi pada penelitian di CV. Bimanda Elektronik ini tidak diketahui atau tak tentu, maka ukuran sampel yang digunakan pada penelitian ini mengikuti pedoman penentuan besarnya ukuran sampel untuk populasi besar atau tak terbatas sebagai berikut: (Solimun, 2002 dikutip oleh Purwanti, 2015).

1. Bila pendugaan parameter menggunakan metode kemungkinan maksimum (maximum like lihood estimation) besar sampel yang disarankan adalah 100 hingga 200, dengan minimum sampel adalah 50 .

2. Sebanyak 5 hingga 10 kali jumlah parameter yang ada didalam model.

3. Sama dengan 5 hingga 10 kali jumlah indikator dari keseluruhan variabel.
Indikator dari keseluruhan variabel pada penelitian ini melibatkan sebanyak 12 indikator, sehingga merujuk pada aturan ketiga diperlukan ukuran sampel minimal 5 x 12 atau sebesar 60 .

\section{Pembuatan Kuesioner Tertutup Faktor}

\section{Eksternal Perusahaan}

Pembuatan kuesioner tertutup untuk
faktor eksternal dilakukan untuk menentukan apa saja yang menjadi peluang dan ancaman bagi perusahaan. Pembuatan dilakukan oleh pemilik perusahaan dan tiga pimpinan toko. Sedangkan untuk pengisian responden dilakukan oleh pimpinan, tiga pimpinan toko dan 56 konsumen tetap CV. Bimanda Elektronik.

Menentukan Strategi Perushaan Yang Terbaik Dengan Quantitative Strategic Planning Matriks (QSPM)

Menentukan Strategi Perusahaan yang Terbaik dengan Quantitative Startegis Planning Matriks (QSPM) merupakan tahapan perumusahan strategi yangsi alternative startegi secara obyektif, berdasarkan faktor-faktor keberhasilan penting internal dan eksternal yang diidentifikasi sebelumnya.

Adapun urutan dalam tahapan perumusan matrik QSPM yaitu : 
- Membuat daftar peluang dan ancaman eksternal dan internal

- Memberi Bobot setiap faktor eksternal dan internal

- Melakukan pencocokan dan identifikasi strategi untuk diterapkan

- Menentukan skor daya tarik

- Menentukan skor daya tarik total Perusahaan sebaiknya mampu mengambil keputusan terhadap strategi terbaik dan yang paling cocok yang mereka miliki untuk diterapkan sesuai dengan kondisi internal dan eksternal perusahaan yakni setelah melalui tahap input dan pencocokan. Pemberian skor dilakukan oleh pimpinan $\mathrm{CV}$. Bimanda Elektronik dan beberapa kepala toko atau karyawan.

\section{HASIL PENELITIAN}

\section{A. Analisa Lingkungan Internal dan \\ Eksternal Perusahaan}

Dari hasil penentuan faktor internal dan eksternal diketahui bahwa yang menjadi faktor internal ada 5 faktor untuk kekuatan (Strenghts) dan 9 faktor untuk kelemahan (Weaknesses). Sedangkan untuk faktor eksternal ada 6 faktor untuk peluang (opportunities) dan 6 faktor untuk ancaman (treaths). Adapun bentuk faktor intern dan eksternal dapat dilihat sebagai berikut:

\section{Analisis Lingkungan Internal}

\section{a. Kekuatan (Strengths)}

1) Produk dijual berkualitas produksi pabrik dan bergaransi

2) Harga dipasar bersaing

3) Lokasi perusahaan ada 12 unit cabang

4) Modal yang digunakan CV. Bimanda Elektronik adalah modal sendiri yang didapat dari modal keluarga.

5) Produk yang dijual mudah didapat dari distributor pabrik.

\section{b. Kelemahan (Weakness)}

1) Tidak memiliki sistem manajemen perusahaan

2) Sedikitnya variasi jenis produk yang ditawarkan

3) Minimnya kegiatan pemasaran.

4) Wilayah distribusi masih terbatas

5) Minimnya modal yang dimiliki. 
6) Tidak menggunakan laporan keuangan secara rapi atau menggunakan barbasis media elektronik.

7) Kapasitas penjualan masih terbatas.

8) Tidak adanya riset dan pengembangan pemasaran.

9) Tidak menggunakan website atau sistem database.

\section{Analisis Lingkungan Eksternal}

\section{a. Peluang (Opportunities)}

1) Bertambahnya populasi penduduk.

2) Perkembangan dunia elektronik.

3) Ketersediaan produk elektronik yang banyak.

4) Banyak agen distributor.

5) Tingginya loyalitas konsumen terhadap produk elektronik.

6) Pangsa pasar masih luas.

\section{b. Ancaman (Treathts)}

1) Kenaikan harga produk elektronik

2) Terbukanya pasar online

3) Fluktuasi nilai tukar rupiah

4) Pola hidup masyarakat yang modern

5) Banyak penjual elektronik modern
6) Banyak

produk subtitusi/pengganti

\section{B. Analisa Penentuan Populasi dan Sampel}

Untuk menentukan faktor eksternal yang tepat perlu di dapat dari respon konsumen dan respon pihak perusahaan. Adapun jumlah sampel yang diketahui sebagai responden ialah sebanyak 60 responden yang terdiri dari 4 dari pihak perusahaan dan 56 dari pihak konsumen tetap yang menjadi responden untuk faktor eksternal.

\section{Analisa Pembuatan Kuesioner}

\section{Tertutup}

Dari hasil pembuatan kuesioner tertutup untuk menentukan apa saja yang menjadi peluang dan ancaman. Adapun jumlah kuesinoer tertutup untuk faktor eksternal yang dibuat adalah sebanyak 6 pernyataan untuk peluang dan 6 pernyataan untuk ancaman. Berikut bentuk kuesioner

\section{Analisis Lingkungan Eksternal}

\section{a. Peluang (Opportunities)}

1) Bertambahnya populasi penduduk.

2) Perkembangan dunia elektronik. 
3) Ketersediaan produk elektronik yang banyak.

4) Banyak agen distributor.

5) Tingginya loyalitas konsumen terhadap produk elektronik.

6) Pangsa pasar masih luas.

\section{b. Ancaman (Treathts)}

1) Kenaikan harga produk elektronik

2) Terbukanya pasar online

3) Fluktuasi nilai tukar rupiah

4) Pola hidup masyarakat yang modern

5) Banyak penjual elektronik modern

6) Banyak produk subtitusi/pengganti

\section{Analisa Uji Validitas dan Relaibilitas}

Dari hasil uji validitas dan reliabilitas pada pernyataan kuesioner tertutup untuk faktor eksteral diketahui bahwa semua pernyataan yang diuji valid dan reliabilitas. Hasil dari uji validitas pada pernyataan peluang (opportunities) diketahui bahwa sebanyak 5 (lima) instrumen memiliki nilai $r_{\text {hitung }}$ terbesar yakni sebesar 0,852 yakni pada pernyataan modal yang digunakan $\mathrm{CV}$. Bimanda Elektronik adalah modal sendiri yang didapat dari modal keluarga, selanjut nilai $r_{\text {hitung }}$ sebesar 0,757 yakni pada pernyataan produk yang dijual didapat dari distributor pabrik, selanjutnya nilai $r_{\text {hitung }}$ sebesar 0,717 yakni pada pernyataan produk

dijual berkualitas produksi pabrik dan bergaransi, selanjutnya nilai $\mathbf{r}_{\text {hitung }}$ sebesar 0,663 yakni pada pernyataan harga dipasar bersaing, selanjutnya nilai $r_{\text {hitung }}$ sebesar 0,609 yakni pada pernyataan lokasi perusahaan ada 12 unit cabang. Sedangkan hasil validitas pada pernyataan ancaman (treaths) diketahui bahwa sebanyak 6 (enam) isntrumen memiliki nilai $r_{\text {hitung terbesar yakni sebesar }}$ 0,836 yakni pada pernyataan minimnya kegiatan pemasaran, selanjutnya nilai $\mathrm{r}_{\text {hitung }}$ sebesar 0,836 yakni pernyataan pada pernyataan tidak menggunakan laporan keuangan secara rapi atau menggunakan sistem keuangan berbasis media elektronik, selanjutnya nilai $\mathrm{r}_{\text {hitung }}$ sebesar 0,715 yakni pernyataan kapasitas penjualan masih terbatas, selanjutnya nilai $r_{\text {hitung }}$ sebesar

0,715 yakni pernyataan tidak adanya riset dan pengembangan pemasaran, selanjutnya nilai $r_{\text {hitung }}$ sebesar 0,668 yakni pernyataan tidak memiliki sistem manajemen perusahaan, selanjutnya nilai $r_{\text {hitung }}$ sebesar 0,526 yakni 
pernyataan wilayah distribusi masih terbatas, selanjutnya nilai $r_{\text {hitung }}$ sebesar 0,465 yakni pernyataan minimnya modal yang dimiliki, selanjutnya nilai $\mathrm{r}_{\text {hitung }}$ sebesar 0,441 yakni pernyataan sedikitnya variasi jenis produk yang ditawarkan dan nilai $\mathrm{r}_{\text {hitung }}$ sebesar 0,365 yakni pernyataan tidak menggunakan website atau sistem database.

\section{E. Analisa Menentukan Faktor Internal dan Eksternal Perusahaan}

Hasil perhitungan yang telah dilakukan pada faktor internal diketahui bahwa pernyataan yang memiliki skor paling tinggi pada kekuatan (Strengths) yaitu produk dijual berkualitas produksi pabrik dan bergaransi dengan nilai skor 0,347. Sedangkan untuk pernyataan yang paling lemah untuk kelemahan (Weakness) yaitu tidak menggunakan website atau sistem database memiliki skor 0,092.

Hasil perhitungan yang telah dilakukan pada faktor eksternal diketahui bahwa pernyataan yang memiliki skor paling tinggi pada peluang (opportunities) yaitu tingginya loyalitas konsumen terhadap produk elektronik dengan nilai skor 0,358. Sedangkan untuk pernyataan yang menjadi utama terhadap ancama (treathts) ialah yaitu banyak produk subtitusi/pengganti dengan skor 0,311 .

Sedangkan hasil matriks internaleksternal (IE) nilai rata-rata IFAS sebesar 2,336 dan rata-rata EFAS 3,187 menunjukkan posisi CV.Bimanda Elektronik berada pada kuadra II yang artinya perusahaan dalam tahap pertumbuhan dan strategi yang tepat untuk digunakan adalah strategi menjaga dan mempertahankan yang diantaranya strategi penetrasi pasar, pengembangan pasar dan produk.

\section{F. Analisa Merumuskan Strategi Peningkatan Penjualan}

1. Menganalisis strategi pemasaran dalam meningkatkan produk elektronik pada CV. Bimanda Elektronik menggunakan analisis SWOT. Analisis SWOT terdiri dari faktor internal dan faktor ekternal. Dapat di ketahui bahwa dari faktor internal perusahaan CV. Bimanda Elektronik memiliki skor 2,336, skor ini dibawah 2,5 yang berarti menggambarkan posisi internal perusahaan yang lemah. Pada faktor eksternal perusahaan CV. Bimanda Elektronik memiliki skor 3,187 skor ini mendekati skor 4,0 yang menggambarkan perusahaan ini 
merespon peluang yang ada dan cukup mampu menghindari ancaman yang ada di pasar industri.

2. Matrik IE merupakan yang dapat digunakan untuk mengetahui seberapa kuat dan tinggi perusahaan. Matrik ini dilihat melalui skor yang terdapat pada faktor internal dan faktor eksternal perusahaan. Jika di konversikan skor ini berada pada kotak 2 berada pada fase growth atau pertumbuhan yang berkonsentrasi melalui integrasi horizontal. Pada keadaan ini perusahaan dapat memaksimalkan promosi pada pemasaran lokal dan mempertahankan kualitas produk yang dijual.

\section{G. Analisa Menentukan Strategi Perusahaan Yang Terbaik Dengan Quantitative Strategic Planning Matriks (QSPM).}

Pada analisa QSPM terdapat 10

alternatif strategi untuk peningkatan penjualan produk elektronik. Adapun yang menjadi alternatif strategi yang paling diminati serta menjadi prioritas untuk dilakukan oleh perusahaan yakni melakukan kegiatan iklan dan promosi untuk menarik pelanggan potensial dan memperluas daerah pemasaran dengan nilai skor TAS sebesar (6,568). Alternalif strategi ini lebih diprioritaskan dikarenakan selama ini perusahaan sangat kurang aktif dalam melakukan promosi dan kurang aktif dalam memperluas daerah pemasaran produk dari CV. Bimanda Elektronik. Selain itu mempertahankan harga dan tetap menjaga kualitas produk untuk meningkatkan kepuasan dan loyalitas konsumen di CV. Bimanda Elektronik.

Alternatif strategi yang paling tidak diminati yaitu membangun atau membuat laporan keuangan secara rapi dan terintegrasi dengan sistem computer dengan skor TAS sebesar $(4,682)$. Alternatif strategi ini tidak diminati oleh pemilik mengingat usaha yang dijalankan masih berskala kecil atau menengah yang dapat mereka jalankan sendiri tanpa menggunakan sistem manajeman perusahaan dan sampai saat ini usaha tersebut masih dapat bertahan, meskipun pada dasarnya semua usaha mikro ataupun makro perlu adanya penerapan sistem manajemen perusahaan untuk mengatur suatu perencanaan, penyusunan, pengarahan, dan pengawasan suatu usaha untuk kedepannya.

\section{KESIMPULAN}


Berdasarkan hasil penelitian dapat ditarik beberapa kesimpulan yaitu:

1. Faktor lingkungan internal dan eksternal perusahaan yang mempengaruhi strategi pemasaran yaitu: untuk faktor internal perusahaan kekuatan utama perusahaan berada pada produk yang dijual berkualitas produksi pabrik dan bergaransi dan kelemahan utama CV. Bimanda Elektronik yaitu tidak menggunakan website atau sistem database. Sedangkan untuk faktor eksternal perusahaan peluang utama yang dimiliki oleh perusahaan berupa, tingginya loyalitas konsumen terhadap produk elektronik, sedangkan ancaman utama untuk perusahaan adalah banyaknya produk substitusi/ pengganti. Hasil dari penilaian matrik IE menunjukkan posisi CV. Bimanda Elektronik berada pada posisi kuadran II. pada posisi ini strategi yang tepat untuk digunakan adalah strategi meningkatkan, dan mempertahankan.

2. Hasil dari analisis SWOT menghasilkan 10 alternatif strategi yang dapat dipilih oleh CV. Bimanda Elektronik yaitu:
1) Melakukan kegiatan promosi dan iklan untuk menarik pelanggan potensial dan memperluas daerah pemasaran.

2) Mempertahankan harga dan tetap menjaga kualitas produk untuk meningkatkan kepuasan dan loyalitas konsumen.

3) Menciptakan promosi produk dengan bentuk dan jenis yang baru.

4) Membangun dan menjalankan sistem manajemen organisasi internal perusahaan.

5) Membangun usaha patungan (Joint Venture) dengan pihak yang menyediakan modal dan produk untuk meningkatkan kapasitas penjualan.

6) Meningkatkan kegiatan pemasaran.

7) Menggunakan website atau sistem databasae

8) Menjalin kerjasama dengan agen distributor yang potensial untuk menambah pangsa pasar.

9) Memanfaatkan lokasi yang strategis untuk menarik pelanggan yang potensial.

10) Membangun atau membuat laporan keuangan secara rapi 
dan terintegrasi dengan sistem komputer

3. Adapun hasil analisis dengan menggunakan matrik QSPM, dari sepuluh alternatif strategi yang ada terdapat satu alternatif strategi yang diprioritaskan untuk dilakukan oleh perusahaan yaitu, melakukan kegiatan promosi dan iklan untuk menarik pelanggan potensial dan memperluas daerah pemasaran dengan skor TAS, sebesar 6,568

\section{DAFTAR PUSTAKA}

[1] Aliyah, Zulfa. 2018. Analisis Startegi Pemasaran Dalam Meningkatkan Penjualan Ekspor Kopi Arabika Pada CV Yudi Putri. Skripsi Program Studi Ekonomi Islam. Fakultas Ekonomi dan Bisnis Islam. Universitas Islam Negeri Sumatera Utara.

[2] Azirwan, Mustakim. 2014. Perancangan Strategi Bauran Pemasaran (7P) Berdasarkan Analisis Segmenting, Targeting, dan Positioning Untuk Meningkatkan Penjualan Pada Usaha Royal Pizza Pekanbaru. Skripsi Jurusan Teknik Industri. Fakultas Sains dan Teknologi. Universitas Islam Negeri SultanSyarif Kasim Riau. http://repository.uin- suska.ac.id/ di akses 10 Agustus 2020.

[3] Bahri, Syaiful. 2018. Usulan Strategi Pemasaran Perumahan Graha Bintang Menggunakan Metode QSPM (Quantitative Strategic Planning Matrix). Skripsi Program Studi Teknik Industri. Fakultas Sains Dan Teknologi UIN Suska.

[4] David, F.R. 2002. Manajemen Strategis. Edisi Bahasa Indonesia. Jakarta : PT. Prenhallindo.
[5] David dan Fred. 2009. Manajemen Strategi.Konsep Terjemahan.Edisi keduabelas. Jakarta: PT. Indeks.

[6] David dan Fred. 2010. Strategic management. Manajemen Strategis. Edisi Keduabelas. Jakarta: Erlangga.

[7] Gaol, Agoesd P.Lumban. 2013. Strategi PromotionalMix Dalam Meningkatkan Penjualan PadaPT. Polgabe Paltria Sejahtera Pekanbaru Riau.Skripsi Program Studi Manajemen. Fakultas Ekonomi. Universitas Sumatera Utara.

[8] Kotler, P., \& Amstrong, G. 2008. Prinsip Prinsip Pemasaran . Jakarta: Erlanga.

[9] Purwanti, Neni Dyah, Sugiono, Dewi Hardiningtyas. 2015. Analisis Pengaruh Kualias Pelayanan Dan Citra Perusahaan Terhadap Kepuasan Dan Loyalitas Pelanggan. Jurnal Rekayasa Dan Manajemen Sistem Industri Vol.3 No.2 Teknik Industri Universitas Brawijaya

[10] Putri, Nyimas Ekinevita, Retno Astuti dan Shyntia Atica Putri. 2014. Perencanaan Strategi pengembangan Restauran menggunakan Analisis SWOT danMatriks QSPM (Quantitative Strategic Planning Matriks (Studi Kasus Restoran Big Burger Malang). Skripsi Jurusan Teknik Industri Pertanian.Fakultas Pertanian. Universitas Brawijaya. Malang Jawa Timur. http: skripsitip.staff.ub.ac.id// diakses 18 Agustus 2020.

[11] Ramadhan, Ahmad. 2013.Analisis SWOT Sebagai Landasan Dalam Menentukan Strategi Pemasaran (Studi Mc Donald's Ring Road). Jurnal. Jurusan Manajemen. Fakultas Ekonomi. Universitas Sumatera Utara. Medan. http: jurnal.usu.ac.id/ diakses 24 Agustus 2020. 
[12] Rangkuti, Freddy. 2014. Analisis SWOT Teknik Membedah Kasus Bisnis. Jakarta: Gramedia Putaka Utama.

[13] Salusu, J. 2015. Pengambilan Keputusan Stratejik Untuk Organisasi Publikdan Organisasi Non Profi. Jakarta: Grasindo.

[14] Saputra, Oki. 2016. Perancangan Strategi Pemasaran Keripik Nenas Dan Keripik Nangka Dengan Menggunakan Pendekatan SWOT Dan QSPM Di Home Industry Sinar Hidayah. Skripsi Program Studi Teknik Industri. Fakultas Sains Dan Teknologi. UIN Suska.

[15] Sari, Resky Kumala. 2018. Analisa Strategi Pemasaran Pada UKM Roman Indah Menggunakan Metode SWOT dan Metode QSPM (Quantitative Strategic Planning Matrix). Skripsi Program Studi Teknik Industri. Fakultas Sains Dan Teknologi. UIN Suska.

[16] Sugiyono. 2006. Metode Penelitian Administrasi. Bandung: Alfabeta.

[17] Tjiptono, Fandy. 2000. Perspektif Manajemen dan Pemasaran Kontemporer, Yogyakarta: Andi Yogyakarta.

[18] Wijaya, Arik Adi. 2013. Analisis Strategi Pemasaran Makanan Tradisional" (Studi Kasus pada Home Industry Rengginang Halimatus sa'diyah Kalibaru di Kabupaten Banyuwangi). Skripsi. Jurusan Manajemen. Fakultas Ekonomi. Universitas Jember. Banyuwangi. http://dspace.Unej.ac.id/ diakses 23 Agustus 2020.

[19] Yunita, Tengku Eva. 2019. Analisa Strategi Pemasaran Produk Daur Ulang Plastik Dengan Menggunakan Metode SWOT dan QSPM (Quantitative Strategic
Planning Matrix) Di Dalang Collection. Skripsi Program Studi Teknik Industri. Fakultas Sains Dan Teknologi. UIN Suska. 